\title{
MODEL PERTUMBUHAN DIAMETER DAN TINGGI POHON LIMA JENIS DIPTEROCARPACEAE DI HUTAN PENELITIAN CARITA - BANTEN
}

\author{
The Growth Models of Tree Diameter and Tree Height for Five Dipterocarps Species in \\ Forest Research Station of Carita, Banten
}

\author{
Sofwan Bustomi ${ }^{1}$, Rinaldi Imanuddin ${ }^{2)}$ dan/and Nina Mindawati ${ }^{1)}$ \\ ${ }^{1)}$ Pusat Penelitian dan Pengembangan Hutan Tanaman, Gunung Batu, Bogor \\ Kampus Balitbang Kehutanan, Jl. Gunung Batu No. 5, Bogor 16610 \\ Telp. (0251) 8631238, Fax. (0251) 7520005 \\ ${ }^{2)}$ Pusat Penelitian dan Pengembangan Hutan dan Konservasi Alam \\ Kampus Balitbang Kehutanan, Jl. Gunung Batu No. 5, Bogor 16610 \\ Telp. (0251) 7520067, Fax. (0251) 633111
}

Naskah masuk : 2 April 2008 ; Naskah diterima : 15 Januari 2009

\begin{abstract}
Growth models of five Dipterocarps species were constructed by using Alder (1980) model i.e. Ln $Y=a+b(1 / A)^{k}$ and other model which was available in Curve Expert version 1.37 software, namely: $\operatorname{Hoerl}\left(Y=a b^{X} X^{c}\right)$, Quadratic Fit $(Y=a+b X+c X 2)$, Gompertz $\left(Y=a e^{-e b-c x}\right), \operatorname{Logistic}\left(\mathrm{Y}=\mathrm{a} /\left(1+\mathrm{be}^{-\mathrm{cx}}\right)\right.$, and Exponential Association $\left(Y=a\left(1-e^{b X}\right)\right.$ models etc, which $Y$ : diameter $(\mathrm{cm})$ or height $(\mathrm{m})$ growth variable, $X$ : tree age (year); e:natural constant $=2.718$, and a,b,c, $d$ as regression coeffisient. Based on the criteria of mean deviation $(S R R<10 \%)$ and aggregative deviation $(S A R<1 \%)$ were resulted the growth models of tree diameter and tree height for each species which have studied.
\end{abstract}

Keywords: Dipterocarps, growth model, tree diameter, tree height, mean deviation and aggregative deviation

\begin{abstract}
ABSTRAK
Model pertumbuhan lima jenis Dipterocarpaceae dibuat dengan menggunakan model Alder (1980) yaitu $\operatorname{Ln} \mathrm{Y}=\mathrm{a}+\mathrm{b}(1 / \mathrm{A})^{\mathrm{k}}$ dan model-model lain yang tersedia dalam perangkat lunak Curve Expert versi 1.37 yaitu model Hoerl $\left(Y=a b^{x} X^{c}\right)$, Quadratic Fit $(Y=a+b X+c X 2)$, Gompertz $\left(Y=a e^{-e^{b-c x}}\right)$, Logistic $\left(Y=a /\left(1+b e^{-c X}\right)\right.$, dan Exponential Association $\left(Y=a\left(1-e^{b X}\right)\right.$, dan lain-lain; dimana, $Y$ adalah peubah pertumbuhan diameter $(\mathrm{cm})$ atau tinggi pohon $(\mathrm{m})$; $\mathrm{X}$ adalah umur pohon (tahun); e adalah bilangan alam sebesar 2.718; a,b,c,d adalah koefisien regresi. Berdasarkan kriteria simpangan rata-rata relatif $(\mathrm{SRR}<10 \%)$ dan simpangan agregatif relatif (SAR $<1 \%$ ), dihasilkan model pertumbuhan diameter pohon dan tinggi pohon untuk masing-masing jenis yang diteliti.
\end{abstract}

Kata kunci: Dipterocarpaceae, model pertumbuhan, diameter pohon, tinggi pohon, simpangan rata-rata relatif, dan simpangan agregatif relatif 


\section{PENDAHULUAN}

Pelaksanaan pembangunan hutan tanaman industri (HTI) didasarkan pada kenyataan meningkatnya kebutuhan akan sumber bahan baku kayu bagi industri-industri perkayuan serta keadaan hutan alam yang sudah tidak dapat menjamin kontinuitas produksi kayu. Dalam pengelolaan hutan tanaman yang sudah terbangun, salah satu tahapan penting dalam pengembangannya adalah mempelajari variasi dari perbedaan sifat-sifat dan dinamika pertumbuhan tanaman.

Pertumbuhan diartikan sebagai pertambahan dimensi pohon atau tegakan hutan selama periode waktu tertentu (Vanclay, 1994). Dinamika pertumbuhan pohon/tegakan dapat diduga menggunakan suatu model matematis hubungan antara parameter-parameter pertumbuhan: jumlah pohon, luas bidang dasar, diameter, tinggi maupun umurnya. Dengan model matematis yang disusun akan dapat digunakan untuk memproyeksikan hasil tegakan yang akan dipanen secara lestari diakhir rotasi yang ditetapkan.

Menurut Suhendang (1996) berdasarkan periode yang dipakai sebagai dasar dalam perhitungannya, pertumbuhan dan hasil dapat mengandung dua arti, yaitu tingkat (level) dan laju. Pertumbuhan dan hasil dalam arti total menunjukkan jumlah sampai periode waktu tertentu, sedangkan dalam arti laju menunjukkan jumlah untuk waktu tertentu, biasanya dinyatakan untuk setiap tahun. Laju pertumbuhan tegakan sebagai riap $\left(\mathrm{m}^{3} / \mathrm{ha} /\right.$ tahun), sedangkan banyaknya volume kayu maksimum yang dipanen per periode (tahun) disebut etat hasil. Pengelolaan hutan akan berada pada tingkat kelestarian hasil apabila besarnya etat sama dengan riap tegakan.

Penelitian ini bertujuan untuk mendapatkan model pertumbuhan diameter dan tinggi pohon dari jenis-jenis yang diintroduksi di Hutan Penelitian (HP) Carita, meliputi lima jenis dari famili Dipterocarpaceae (Shorea ovalis, S. leprosula, S. selanica, Hopea mengerawan dan H. dryobalanoides) yang ditanam antara tahun 1955-1956. Kelima jenis tersebut dipilih berdasarkan kelengkapan data hasil pengukuran berulang, serta mengingat populasi jenis-jenis dari famili ini ditempat asalnya (terutama di Kalimantan dan Sumatera) sudah menurun drastis.

\section{KEADAAN UMUM LOKASI PENELITIAN}

\section{A. Letak dan luas}

HP Carita dibangun pada tahun 1955 dengan luas total 50 hektar yang terdiri dari 10 ha Carita I (CI) dan 40 ha Carita II (CII), dan terletak kira-kira $10 \mathrm{~km}$ dari kota Labuan. Menurut administrasi pemerintah, HP carita termasuk wilayah Desa Sukarame, Kecamatan Labuan, Kabupaten Pandeglang, Propinsi Banten. Sedangkan menurut administrasi kehutanan termasuk wilayah Resort Polisi Hutan (RPH) Carita, Bagian Kesatuan Pemangkuan Hutan (KPH) Banten, Perum Perhutani Unit III Jawa Barat.

\section{B. Iklim}

Berdasarkan data curah hujan selama 10 tahun (tahun 1990-2000), HP Carita memiliki tipe curah hujan BB $(\mathrm{Q}=32 \%)$, menurut Schmidt dan Ferguson (1956) dengan curah hujan rata-rata sebesar 3.959 $\mathrm{mm}$ per tahun dengan curah hujan yang tinggi terjadi pada bulan Januari sampai April, sedangkan curah hujan yang rendah terjadi pada bulan Juni sampai September. Suhu berkisar antara $22,06^{\circ} \mathrm{C}$ sampai $32,35^{\circ} \mathrm{C}$ dan kelembaban nisbi rata-rata berkisar antara $77,4 \%$ sampai $85,0 \%$.

\section{Tanah}

Jenis tanah di HP Carita yaitu Aluvial Kelabu Tua dengan bahan induk endapan liat. Secara umum sifat fisik tanah adalah tekstur liat, struktur pejal, konsistensi teguh (lembab), plastis (basah), 
keras (kering) tanpa batas horizon, warna kelabu hingga coklat, tanpa solum sampai sedang, sedangkan sifat kimianya adalah bahan organik rendah, kejenuhan basa sedang hingga tinggi dengan adaptasi tinggi, kemasaman bervariasi dan permeabilitas rendah.

\section{Potensi Jenis-jenis Dipterocarpaceae}

HP Carita mempunyai koleksi jenis sebanyak 45 jenis pohon, yang terdiri dari jenis Dipterocarpaceae 16 jenis dan non Dipterocarpaceae 29 jenis. Jenis-jenis Dipterocarpaceae yang tumbuh baik di HP Carita adalah : Shorea compressa Burck, S. leprosula Miq, S. ovalis Bl, S. palembanica Miq, S. pinanga Scheff, S. stenoptera Burck.f, S. selanica Bl, S. mecistopteryx Ridl, Hopea bancana V.Sl, H. mengarawan Miq, H. odorata Roxb, H. dryobalanoides Miq, H. nigra Burck, Dipterocarpus haseltii B1, D. gracilis Bl dan Vatica sumatrana V.S1. Model pertumbuhan yang dibuat untuk jenis Shorea ovalis ( petak 2/C1), Shorea leprosula (petak 1,2,5,3,4,8/C1 dan petak $5,34 \mathrm{a}, 17 \mathrm{c}, 36 \mathrm{~b}, 39,17 \mathrm{a}, 19 \mathrm{~b}, 36 \mathrm{a}, 17 \mathrm{~b} / \mathrm{CII}$ ), Shorea selanica (petak 7/C1dan petak 27,45a,38b,17d,19b,45b/CII), Hopea mengarawan (petak 4,5,8/CI daan petak 30b,18b,18d,31c/CII\} dan jenis Hopea dryobalanoides (petak 1,3,4,/CI).

\section{METODE PENELITIAN}

\section{A. Pengumpulan Data}

Dalam pembuatan model pertumbuhan diameter dan tinggi pohon untuk jenis $S$. ovalis, $S$. leprosula, S. selanica, H. mengerawan dan H. dryobalanoides di HP Carita, data diperoleh dari hasil pengukuran pada 25 petak coba permanen dengan luas masing-masing petak 0,25 ha, dimana petak-petak tersebut tersebar pada areal seluas 50 ha.

Data pertumbuhan diambil dari hasil pengukuran secara periodik sejak ditanam dengan periode pengukuran tidak tetap; pengukuran terakhir terhadap jenis-jenis tersebut dilakukan pada tahun 2003. Parameter yang diamati adalah diameter setinggi dada (atau $20 \mathrm{~cm}$ di atas banir bagi pohon berbanir lebih dari 1,10 m) dan tinggi pohon (total dan bebas cabang). Diameter diukur dengan menggunakan phi-band atau pita keliling, sedangkan tinggi diukur dengan menggunakan hagameter.

\section{B. Pengolahan dan Analisis Data}

1. Penyusunan model

Model pertumbuhan diameter pohon dan tinggi pohon yang disusun didasarkan pada persamaan hubungan antara diameter/tinggi pohon dengan umurnya. Dalam penelitian ini, model pertumbuhan tersebut dianalisis menggunakan model yang dikembangkan oleh Alder (1980) yaitu : $\operatorname{Ln} Y=a+b(1 / A)^{k}$ dengan $\mathrm{Y}$ adalah peubah pertumbuhan (diameter, tinggi), A adalah umur (tahun) dan a, b, k adalah konstanta (parameter model). Dalam pembentukan persamaan, tetapan-k dihitung dengan cara iterasi, dimana besaran tetapan-k yang dipilih adalah besaran yang menghasilkan persamaan yang mempunyai jumlah kuadrat sisaan terkecil.

Selain model pertumbuhan di atas, juga akan dianalisis model pertumbuhan lainnya dengan menggunakan perangkat lunak Curve Expert versi 1.37. yang mencakup Hoerl Model, Quadratic Fit, Gompertz Model, Logistic Model, dan lain sebagainya. Adapun model persamaan umum yang dibuat untuk mendapatkan model pertumbuhan diameter dan tinggi pohon adalah sebagai berikut: 


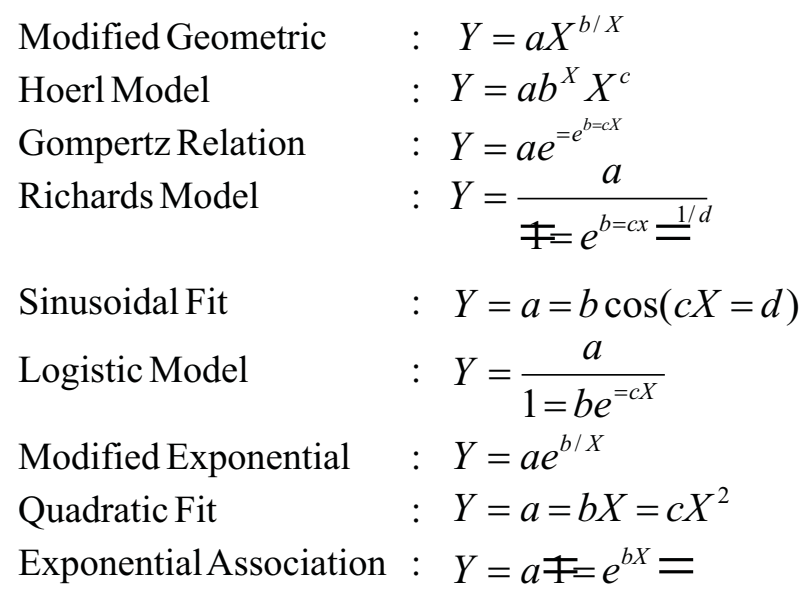

Dimana, $\mathrm{Y}$ adalah peubah pertumbuhan diameter $(\mathrm{cm})$ atau tinggi pohon $(\mathrm{m})$; $\mathrm{X}$ adalah umur pohon (tahun); e adalah bilangan alam sebesar 2.718; a,b,c,d adalah koefisien regresi.

\section{Uji Keterandalan Model}

Untuk menguji keterandalan (reliability) model, didasarkan pada kriteria nilai simpangan agregatif dan simpangan rata-rata yang dihasilkan. Mengingat belum ditemukan standar atau batasan terhadap kriteria nilai simpangan yang digunakan dalam penyusunan model pertumbuhan, maka batasan yang digunakan mengacu pada batasan dalam menilai model pendugaan isi pohon yang baik yaitu simpangan rata-rata relatif(SRR) kurang dari 10\% dan simpangan agregatif relatif(SAR) kurang dari 1\% (Spurr, 1952; Husch, 1963; Prodan, 1965; dan Marcelino, 1966). Selain itu, kriteria yang digunakan untuk menentukan model terbaik adalah besarnya koefisien determinasi $\left(\mathrm{R}^{2}\right)$ dan galat baku $(\mathrm{Se})$, dimana model yang dipilih adalah model yang mempunyai nilai $\mathrm{R}^{2}$ paling tinggi dan Se paling kecil.

\section{HASIL DAN PEMBAHASAN}

\section{A. Model Pertumbuhan Diameter Pohon}

Dari hasil analisis data, model pertumbuhan diameter pohon yang didapat baik dengan menggunakan model yang digunakan Alder (1980) maupun dengan menggunakan perangkat lunak Curve Expert untuk masing-masing jenis dapat dilihat pada Tabel 1.

Besarnya $\mathrm{R}^{2}$ dan Se sebagai sebagai ukuran tingkat ketelitian model serta besarnya SRR dan SAR sebagai ukuran untuk menguji keterandalan dan pemilihan model terbaik dari masing-masing model yang tersusun tercantum dalam Tabel 2.

Pada Tabel 2 dapat dilihat bahwa semua persamaan model pertumbuhan diameter yang dihasilkan mempunyai nilai koefisien determinasi $\left(\mathrm{R}^{2}\right)$ yang sangat baik yaitu hampir seluruh persamaan menghasilkan nilai $\mathrm{R}^{2}$ lebih dari $99 \%$. Selain itu, besarnya galat baku (Se) yang dihasilkan relatif kecil, dimana hampir semua persamaan mempunyai nilai galat baku yang lebih kecil dari 1. Dengan demikian dapat dikatakan bahwa persamaan-persamaan model pertumbuhan diameter pohon di atas mempunyai kriteria sebagai model yang baik. 
Tabel(Table) 1. Model pertumbuhan diameter pohon untuk lima jenis dipterocarpaceae di Hutan Penelitian Carita, Banten (Growth model of tree diameter for five dipterocarps species in forestresearch station of Carita, Banten)

\begin{tabular}{|c|c|c|c|}
\hline No. & $\begin{array}{c}\text { Jenis } \\
\text { (Species) } \\
\end{array}$ & $\begin{array}{l}\text { Nama Model } \\
\text { (Models Name) }\end{array}$ & $\begin{array}{l}\text { Persamaan Model } \\
\text { (Models Equation) }\end{array}$ \\
\hline \multirow[t]{2}{*}{1.} & Shorea ovalis & Alder & $\operatorname{Ln} D=5,36641-6,31351(1 / A)^{0,38024}$ \\
\hline & Shorea ovalis & Modified Geometric & $\mathrm{D}=91,68992 \mathrm{~A}^{(-7,81215 / \mathrm{A})}$ \\
\hline \multirow[t]{2}{*}{2.} & Shorea leprosula & Alder & $\operatorname{Ln} \mathrm{D}=4,53026-10,32320(1 / \mathrm{A})^{0,75013}$ \\
\hline & Shorea leprosula & Hoerl Model & $\mathrm{D}=0,13593 * 0,92547^{\mathrm{A}} \mathrm{A}^{2,37515}$ \\
\hline \multirow[t]{2}{*}{3.} & Shorea selanica & Alder & $\operatorname{Ln} \mathrm{D}=4,33539-9,70816(1 / \mathrm{A})^{0,81416}$ \\
\hline & Shorea selanica & Gompertz Relation & $\mathrm{D}=43,02050 \exp (-\exp (1,39883-0,14038 \mathrm{~A}))$ \\
\hline \multirow[t]{2}{*}{4.} & Hopea mengerawan & Alder & $\operatorname{Ln} \mathrm{D}=7,43642-9,44044(1 / \mathrm{A})^{0,27933}$ \\
\hline & Hopea mengerawan & Richards Model & $\begin{array}{l}\mathrm{D}=42,88092 /(1+\exp (7,45690-0,33133 \\
\mathrm{A}))^{0,35097}\end{array}$ \\
\hline 5. & $\begin{array}{l}\text { Hopea } \\
\text { dryobalanoides }\end{array}$ & Alder & $\operatorname{Ln} \mathrm{D}=3,92480-4,20778(1 / \mathrm{A})^{0,47218}$ \\
\hline 6. & $\begin{array}{l}\text { Hopea } \\
\text { dryobalanoides }\end{array}$ & Sinusoidal Fit & $\begin{array}{l}\mathrm{D}=15,30530+5,54299 \cos (0,15939 \mathrm{~A}+ \\
2,28646)\end{array}$ \\
\hline
\end{tabular}

Keterangan (Remarks): D adalah diameter pohon $(\mathrm{cm})$ dan A adalah umur pohon (tahun) $(D$ is tree diameter $(\mathrm{cm})$ and $A$ is tree age (year))

Tabel(Table) 2. Koefisien determinasi $\left(\mathrm{R}^{2}\right)$, galat baku (Se), simpangan agregatif (SAR) dan simpangan rata-rata (SRR) model pertumbuhan diameter pohon lima jenis dipterocarpaceae (Determination coefficient $\left(R^{2}\right)$, standard error (Se), aggregative deviation $(S A R)$ and mean deviation (SRR) of tree diameter growth model for five dipterocarps species)

\begin{tabular}{|c|c|c|c|c|c|}
\hline No. & $\begin{array}{l}\text { Persamaan Model } \\
\text { (Models Equation) }\end{array}$ & $\mathrm{R}^{2}$ & $\mathrm{Se}$ & SAR $(\%)$ & SRR $(\%)$ \\
\hline \multirow[t]{2}{*}{1.} & $\operatorname{Ln} D=5,36641-6,31351(1 / A)^{0,38024}$ & 0,999 & 0,03 & 0,046 & 1,792 \\
\hline & $\mathrm{D}=91,68992 \mathrm{~A}^{(-7,81215 / \mathrm{A})}$ & 0,999 & 0,71 & 0,007 & 1,824 \\
\hline \multirow[t]{2}{*}{2.} & $\operatorname{Ln} \mathrm{D}=4,53026-10,32320(1 / \mathrm{A})^{0,75013}$ & 0,998 & 0,20 & 0,429 & 13,127 \\
\hline & $\mathrm{D}=0,13593 * 0,92547^{\mathrm{A}} \mathrm{A}^{2,37515}$ & 0,999 & 2,30 & 0,130 & 3,541 \\
\hline \multirow[t]{2}{*}{3.} & $\operatorname{Ln} D=4,33539-9,70816(1 / A)^{0,81416}$ & 0,999 & 0,09 & 0,604 & 5,273 \\
\hline & $\mathrm{D}=43,02050 \exp (-\exp (1,39883-0,14038 \mathrm{~A}))$ & 0,999 & 0,60 & $-0,042$ & 2,244 \\
\hline \multirow[t]{2}{*}{4.} & $\operatorname{Ln} D=7,43642-9,44044(1 / A)^{0,27933}$ & 0,999 & 0,03 & 0,112 & 1,998 \\
\hline & $\begin{array}{l}\mathrm{D}=42,88092 /(1+\exp (7,45690-0,33133 \\
\mathrm{A}))^{0,35097}\end{array}$ & 0,999 & 0,34 & 0,011 & 0,961 \\
\hline \multirow[t]{2}{*}{5.} & $\operatorname{Ln} D=3,92480-4,20778(1 / A)^{0,47218}$ & 0,999 & 0,10 & 0,611 & 7,024 \\
\hline & $\begin{array}{l}\mathrm{D}=15,30530+5,54299 \cos (0,15939 \mathrm{~A}+ \\
2,28646)\end{array}$ & 0,984 & 2,61 & $-0,001$ & 8,527 \\
\hline
\end{tabular}

Keterangan(Remarks): Jenis dan model persamaan di atas sama dengan yang ditampilkan pada Tabel 1, secara berurutan (The species and equations in Table 2 equal within Table 1, respectively) 
Untuk memilih model-model yang akan digunakan untuk masing-masing jenis, dilakukan penilaian keterandalan model yang dapat dilihat dari besarnya nilai-nilai simpangan yang dihasilkan, baik simpangan agregat maupun simpangan rata-ratanya. Berdasarkan kriteria-kriteria tersebut, maka model pertumbuhan diameter pohon yang dipilih untuk masing-masing jenis adalah sebagai berikut:

- Shorea ovalis

$$
\begin{aligned}
& \text { : } \operatorname{Ln} \mathrm{D}=5,36641-6,31351(1 / \mathrm{A})^{0,38024} \\
& \mathrm{D}=0,13593 * 0,92547^{\mathrm{A}} \mathrm{A}^{2,37515} \\
& \mathrm{D}=43,02050 \exp (-\exp (1,39883-0,14038 \mathrm{~A})) \\
& \text { - Hopea mengerawan : } \mathrm{D}=42,88092 /(1+\exp (7,45690-0,33133 \mathrm{~A}))^{0,35097}
\end{aligned}
$$$$
\text { - Shorea leprosula }
$$$$
\text { - Shorea selanica }
$$$$
\text { - Hopea dryobalanoides: } \operatorname{Ln} \mathrm{D}=3,924804,20778(1 / \mathrm{A})^{0,47218}
$$

\section{B. Model Pertumbuhan Tinggi Pohon}

Dengan menggunakan analisis yang sama dengan penyusunan model pertumbuhan diameter pohon di atas, hasil-hasil yang diperoleh dalam penyusunan model pertumbuhan tinggi pohon dapat dilihat pada Tabel 3 .

\begin{tabular}{|c|c|c|c|}
\hline No. & $\begin{array}{l}\text { Jenis } \\
\text { (Species) }\end{array}$ & $\begin{array}{l}\text { Nama Model } \\
\text { (Models Name) }\end{array}$ & $\begin{array}{l}\text { Persamaan Model } \\
\text { (Models Equation) }\end{array}$ \\
\hline \multirow[t]{2}{*}{1.} & Shorea ovalis & Alder & $\operatorname{Ln} H=3,53695-6,32965(1 / A)^{0,77641}$ \\
\hline & Shorea ovalis & Logistic Model & $H=22,20152 /(1+5,31528 \exp (-0,16778 A))$ \\
\hline \multirow[t]{2}{*}{2.} & Shorea leprosula & Alder & $\operatorname{Ln} H=4,36638-7,61996(1 / A)^{0,60001}$ \\
\hline & Shorea leprosula & Modified Exponential & $H=54,27670 \exp (-17,40770 / A)$ \\
\hline \multirow[t]{2}{*}{3.} & Shorea selanica & Alder & $\operatorname{Ln} H=3,50144-10,18180(1 / A)^{1,04079}$ \\
\hline & Shorea selanica & Quadratic Fit & $\mathrm{H}=0,09066+1,03727 \mathrm{~A}-0,00082 \mathrm{~A}^{2}$ \\
\hline \multirow[t]{2}{*}{4.} & Hopea mengerawan & Alder & $\operatorname{Ln} H=6,51700-6,93323(1 / A)^{0,22100}$ \\
\hline & Hopea mengerawan & $\begin{array}{l}\text { Exponential } \\
\text { Association }\end{array}$ & $H=60,99760(1-\exp (-0,01850 A))$ \\
\hline \multirow[t]{2}{*}{5.} & $\begin{array}{l}\text { Hopea } \\
\text { dryobalanoides }\end{array}$ & Alder & $\operatorname{Ln} H=3,66505-14,99120(1 / A)^{0,96893}$ \\
\hline & $\begin{array}{l}\text { Hopea } \\
\text { dryobalanoides }\end{array}$ & Hoerl Model & $\mathrm{H}=0,11499 * 0,95115^{\mathrm{A}} \mathrm{A}^{2,00872}$ \\
\hline
\end{tabular}

Tabel (Table) 3. Model pertumbuhan tinggi pohon untuk lima jenis dipterocarpaceae di Hutan Penelitian Carita, Banten (Growth model of tree height for five dipterocarps species in forest research station of Carita, Banten)

Keterangan (Remarks): $\mathrm{H}$ adalah tinggi pohon $(\mathrm{m})$ dan A adalah umur pohon (tahun) (H is tree height $(\mathrm{m})$ and $\mathrm{A}$ is tree age (year))

Nilai-nilai koefisien determinasi $\left(\mathrm{R}^{2}\right)$, galat baku (Se) dan simpangan dugaan dari persamaanpersamaan model pertumbuhan tinggi pohon di atas dapat dilihat dalam Tabel 4. 
Tabel (Table) 4. Koefisien determinasi $\left(\mathrm{R}^{2}\right)$, galat baku (Se), simpangan agregatif(SAR) dan simpangan rata-rata (SRR) persamaan-persamaan model pertumbuhan tinggi pohon lima jenis dipterocarpaceae (Determination coefficient $\left(R^{2}\right)$, standard error (Se), aggregative deviation (SAR) and mean deviation (SRR) of tree height growth model for five dipterocarps species)

\begin{tabular}{|c|l|c|c|c|c|}
\hline No. & \multicolumn{1}{|c|}{$\begin{array}{c}\text { Persamaan Model } \\
\text { (Models Equation) }\end{array}$} & $\mathrm{R}^{2}$ & $\mathrm{Se}$ & $\mathrm{SAR}(\%)$ & SRR (\%) \\
\hline 1. & $\mathrm{Ln} \mathrm{H}=3,53695-6,32965(1 / \mathrm{A})^{0,77641}$ & 0,999 & 0,05 & 0,121 & 3,113 \\
\hline & $\mathrm{H}=22,20152 /(1+5,31528 \exp (-0,16778 \mathrm{~A}))$ & 0,999 & 0,71 & 0,032 & 0,974 \\
\hline 2. & $\mathrm{Ln} \mathrm{H}=4,36638-7,61996(1 / \mathrm{A})^{0,60001}$ & 0,999 & 0,14 & 1,041 & 7,825 \\
\hline & $\mathrm{H}=54,27670 \exp (-17,40770 / \mathrm{A})$ & 0,986 & 3,71 & 1,935 & 11,706 \\
\hline 3. & $\mathrm{Ln} \mathrm{H}=3,50144-10,18180(1 / \mathrm{A})^{1,04079}$ & 0,995 & 0,24 & 2,489 & 14,524 \\
\hline & $\mathrm{H}=0,09066+1,03727 \mathrm{~A}-0,00082 \mathrm{~A}^{2}$ & 0,997 & 1,51 & $-0,0007$ & 9,722 \\
\hline 4. & $\mathrm{Ln} \mathrm{H}=6,51700-6,93323(1 / \mathrm{A})^{0,22100}$ & 0,999 & 0,07 & 0,199 & 3,756 \\
\hline & $\mathrm{H}=60,99760(1-\exp (-0,01850 \mathrm{~A}))$ & 0,997 & 1,29 & 0,005 & 0,504 \\
\hline 5. & $\mathrm{Ln} \mathrm{H}=3,66505-14,99120(1 / \mathrm{A})^{0,96893}$ & 0,999 & 0,10 & 0,869 & 7,715 \\
\hline & $\mathrm{H}=0,11499 * 0,95115^{\mathrm{A}} \mathrm{A}^{2,00872}$ & 0,998 & 0,99 & 0,049 & 3,747 \\
\hline
\end{tabular}

Keterangan(Remarks): Jenis dan model persamaan di atas sama dengan yang ditampilkan pada Tabel 3, secara berurutan (The species and equations in Table 4 equal within Table 3, respectively)

Nilai-nilai koefisien determinasi $\left(\mathrm{R}^{2}\right)$ dan galat baku (Se) dari Tabel 4 menunjukkan bahwa modelmodel pertumbuhan tinggi pohon di atas memenuhi kriteria model yang baik. Selanjutnya, pemilihan model yang akan digunakan untuk masing-masing jenis yang didasarkan pada penilaian uji keterandalan (reliability) adalah sebagai berikut :

- Shorea ovalis

- Shorea leprosula

- Shorea selanica

- Hopeamengerawan

- Hopea dryobalanoides

$$
\begin{aligned}
& H=22,20152 /(1+5,31528 \exp (-0,16778 \mathrm{~A})) \\
& \operatorname{Ln} \mathrm{H}=4,36638-7,61996(1 / \mathrm{A})^{0,60001} \\
& H=0,09066+1,03727 \mathrm{~A}-0,00082 \mathrm{~A}^{2} \\
& \mathrm{H}=60,99760(1-\exp (-0,01850 \mathrm{~A})) \\
& \mathrm{H}=0,11499 * 0,95115^{\mathrm{A}} \mathrm{A}^{2,00872}
\end{aligned}
$$

\section{Grafik dan Tabel Dugaan Pertumbuhan Diameter dan Tinggi Pohon}

Dari model-model terpilih di atas, maka pertumbuhan (diameter dan tinggi pohon) dari jenisjenis yang diteliti dapat dilihat perkembangannya dalam bentuk grafik pada Gambar 1, sedangkan nilai dugaan diameter dan tinggi pohon pada tiap umur untuk masing-masing jenis dapat dilihat pada Tabel 5 . 
Gambar(Figure) 1. Grafik pertumbuhan diameter (A) dan tinggi (B) pohon lima jenis dari famili Dipterocarpaceae di Hutan Penelitian Carita, Banten (The growth curve of tree diameter (A) and tree height (B) for five dipterocarps species in Forest Research Station of Carita, Banten)
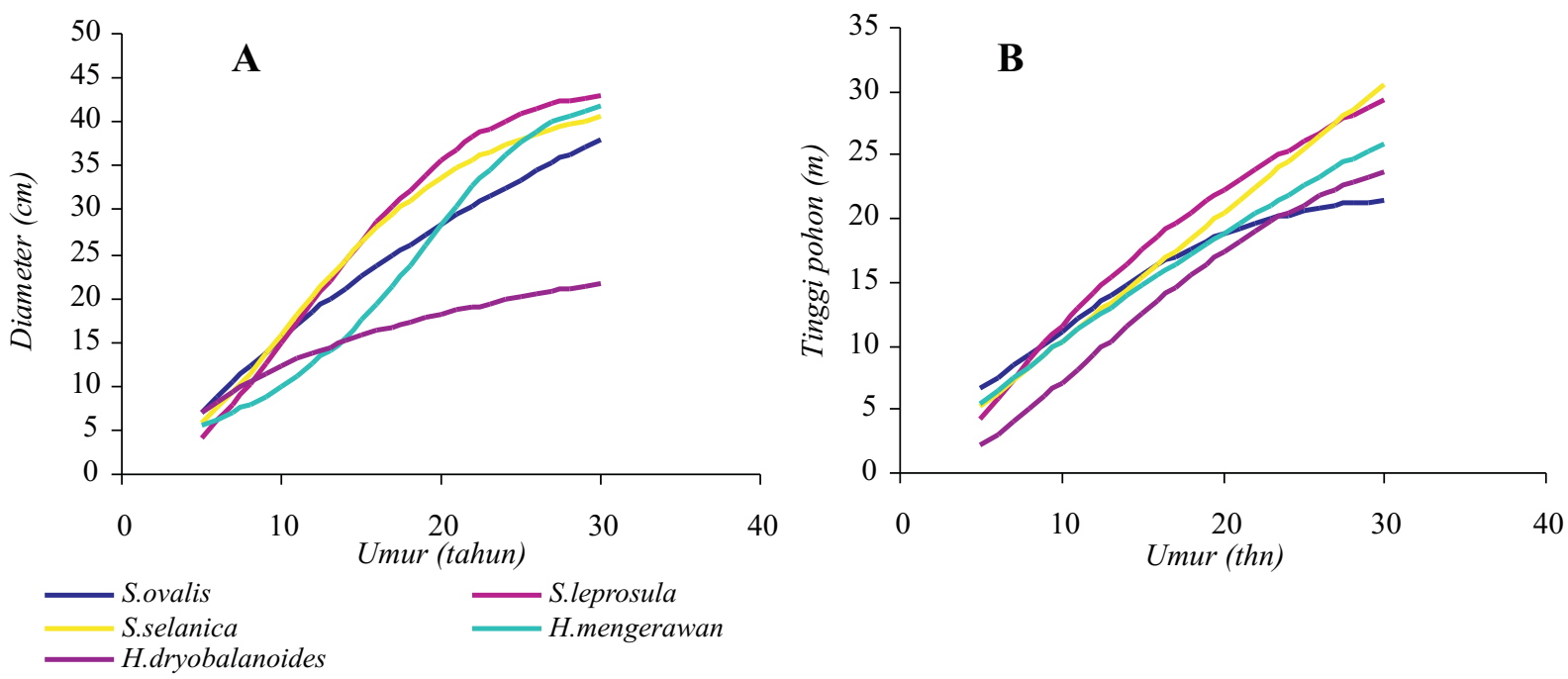

Tabel(Table) 5. Dugaan diameter dan tinggi pohon lima jenis dari famili Dipterocarpaceae di Hutan Penelitian Carita, Banten (Tree diameter and tree height estimated for five dipterocarps species in Forest Research Station of Carita, Banten)

\begin{tabular}{|c|c|c|c|c|c|c|c|c|c|c|}
\hline \multirow{2}{*}{$\begin{array}{l}\text { Umur } \\
\text { (tahun) }\end{array}$} & \multicolumn{2}{|c|}{ Shorea ovalis } & \multicolumn{2}{|c|}{ Shorea leprosula } & \multicolumn{2}{|c|}{ Shorea selanica } & \multicolumn{2}{|c|}{$\begin{array}{c}\text { Hopea } \\
\text { mengerawan }\end{array}$} & \multicolumn{2}{|c|}{$\begin{array}{c}\text { Hopea } \\
\text { dryobalanoides }\end{array}$} \\
\hline & $\mathrm{D}(\mathrm{cm})$ & H (m) & $\mathrm{D}(\mathrm{cm})$ & H (m) & $\mathrm{D}(\mathrm{cm})$ & $\mathrm{H}(\mathrm{m})$ & $\mathrm{D}(\mathrm{cm})$ & $\mathrm{H}(\mathrm{m})$ & $\mathrm{D}(\mathrm{cm})$ & $\mathrm{H}(\mathrm{m})$ \\
\hline 5 & 6.98 & 6.73 & 4.22 & 4.33 & 5.78 & 5.26 & 5.59 & 5.39 & 7.08 & 2.27 \\
\hline 6 & 8.78 & 7.55 & 6.02 & 5.85 & 7.52 & 6.28 & 6.28 & 6.41 & 8.32 & 3.11 \\
\hline 7 & 10.53 & 8.40 & 8.04 & 7.36 & 9.45 & 7.31 & 7.05 & 7.41 & 9.45 & 4.04 \\
\hline 8 & 12.22 & 9.29 & 10.21 & 8.83 & 11.52 & 8.34 & 7.91 & 8.39 & 10.47 & 5.02 \\
\hline 9 & 13.85 & 10.21 & 12.50 & 10.25 & 13.69 & 9.36 & 8.88 & 9.36 & 11.40 & 6.05 \\
\hline 10 & 15.42 & 11.14 & 14.86 & 11.62 & 15.91 & 10.38 & 9.96 & 10.30 & 12.26 & 7.11 \\
\hline 11 & 16.94 & 12.07 & 17.25 & 12.92 & 18.12 & 11.40 & 11.16 & 11.23 & 13.05 & 8.19 \\
\hline 12 & 18.40 & 12.99 & 19.63 & 14.16 & 20.29 & 12.42 & 12.50 & 12.15 & 13.78 & 9.28 \\
\hline 13 & 19.80 & 13.87 & 21.97 & 15.35 & 22.39 & 13.44 & 13.99 & 13.04 & 14.46 & 10.36 \\
\hline 14 & 21.15 & 14.73 & 24.24 & 16.48 & 24.39 & 14.45 & 15.63 & 13.92 & 15.10 & 11.44 \\
\hline 15 & 22.46 & 15.54 & 26.43 & 17.56 & 26.27 & 15.46 & 17.42 & 14.78 & 15.70 & 12.50 \\
\hline 16 & 23.72 & 16.29 & 28.51 & 18.59 & 28.02 & 16.48 & 19.36 & 15.63 & 16.26 & 13.53 \\
\hline 17 & 24.94 & 16.99 & 30.48 & 19.58 & 29.64 & 17.49 & 21.45 & 16.46 & 16.79 & 14.54 \\
\hline 18 & 26.12 & 17.63 & 32.30 & 20.52 & 31.12 & 18.49 & 23.65 & 17.28 & 17.29 & 15.51 \\
\hline 19 & 27.26 & 18.21 & 33.99 & 21.42 & 32.47 & 19.50 & 25.92 & 18.08 & 17.76 & 16.45 \\
\hline 20 & 28.37 & 18.73 & 35.54 & 22.28 & 33.69 & 20.51 & 28.22 & 18.87 & 18.21 & 17.34 \\
\hline 21 & 29.45 & 19.19 & 36.93 & 23.10 & 34.79 & 21.51 & 30.47 & 19.64 & 18.64 & 18.19 \\
\hline 22 & 30.49 & 19.60 & 38.17 & 23.90 & 35.77 & 22.51 & 32.61 & 20.40 & 19.05 & 19.00 \\
\hline 23 & 31.50 & 19.96 & 39.26 & 24.66 & 36.64 & 23.51 & 34.56 & 21.14 & 19.44 & 19.76 \\
\hline 24 & 32.48 & 20.28 & 40.20 & 25.39 & 37.42 & 24.51 & 36.28 & 21.87 & 19.82 & 20.47 \\
\hline 25 & 33.44 & 20.55 & 40.99 & 26.10 & 38.11 & 25.51 & 37.75 & 22.59 & 20.17 & 21.13 \\
\hline 26 & 34.37 & 20.79 & 41.64 & 26.78 & 38.72 & 26.50 & 38.96 & 23.30 & 20.52 & 21.75 \\
\hline 27 & 35.28 & 21.00 & 42.15 & 27.43 & 39.26 & 27.50 & 39.93 & 23.99 & 20.85 & 22.31 \\
\hline 28 & 36.17 & 21.18 & 42.52 & 28.06 & 39.73 & 28.49 & 40.68 & 24.67 & 21.17 & 22.83 \\
\hline 29 & 37.03 & 21.33 & 42.77 & 28.67 & 40.15 & 29.48 & 41.26 & 25.33 & 21.47 & 23.30 \\
\hline 30 & 37.87 & 21.46 & 42.91 & 29.26 & 40.51 & 30.47 & 41.69 & 25.99 & 21.77 & 23.73 \\
\hline
\end{tabular}


Dalam hal yang berhubungan dengan model pertumbuhan, Chapman dan Meyer (1949), Spurr (1952), Husch (1963), Assmann (1970) dan Alder (1980) menerangkan bahwa pada umumnya kurva hubungan antara diameter, tinggi, volume ataupun hasil lainnya dengan umurnya mempunyai bentuk kurva mirip huruf "S". Selanjutnya, Alder (1980) menerangkan bahwa dengan data pengamatan pertumbuhan dimana pengamatan pada suatu umur terpisah dengan umur lainnya, maka akan diperoleh grafik pertumbuhan yang lebih tegak dibandingkan trend pertumbuhan sebenarnya, dan pada kejadian yang sebaliknya akan diperoleh grafik yang lebih datar.

\section{KESIMPULAN}

1. Model pertumbuhan diameter pohon yang dipilih untuk masing-masing jenis adalah sebagai berikut:

- Shorea ovalis

: $\operatorname{Ln} \mathrm{D}=5,36641-6,31351(1 / \mathrm{A})^{0,38024}$

- Shorea leprosula

: $\mathrm{D}=0,13593 * 0,92547^{\mathrm{A}} \mathrm{A}^{2,37515}$

- Shorea selanica

$\mathrm{D}=43,02050 \exp (-\exp (1,39883-0,14038 \mathrm{~A}))$

- Hopea mengerawan

$\mathrm{D}=42,88092 /(1+\exp (7,45690-0,33133 \mathrm{~A}))^{0,35097}$

- Hopea dryobalanoides : Ln D=3,92480 - 4,20778 (1/A $)^{0,47218}$

Kelima persamaan tersebut secara berturut-turut mempunyai nilai simpangan agregat sebesar $0,05 \%$, $0,13 \%,-0,04 \%, 0,01 \%$ dan $0,61 \%$, dan persentase simpangan rata-rata sebesar $1,79 \%, 3,54 \%, 2,24 \%$, $0,96 \%$ dan $7,02 \%$.

2. Model pertumbuhan tinggi pohon yang dipilih untuk masing-masing jenis adalah sebagai berikut:

- Shorea ovalis

$$
\begin{aligned}
& : H=22,20152 /(1+5,31528 \exp (-0,16778 \mathrm{~A})) \\
& : \operatorname{Ln} \mathrm{H}=4,36638-7,61996(1 / \mathrm{A})^{0,60001} \\
& : H=0,09066+1,03727 \mathrm{~A}-0,00082 \mathrm{~A}^{2} \\
& : H=60,99760(1-\exp (-0,01850 \mathrm{~A})) \\
& : H=0,11499 * 0,95115^{\mathrm{A}} \mathrm{A}^{2,00872}
\end{aligned}
$$

- Shorea leprosula

- Shorea selanica

- Hopea mengerawan

Kelima persamaan tersebut secara berturut-turut mempunyai nilai simpangan agregat sebesar $0,03 \%$, $1,04 \%,-0,0007 \%, 0,01 \%$ dan $0,05 \%$, dan persentase simpangan rata-rata sebesar $0,97 \%, 7,83 \%$, $9,72 \%, 0,50 \%$ dan $3,75 \%$.

3. Pertumbuhan diameter dan tinggi pohon untuk lima jenis dipterocarpaceae (Shorea ovalis, Shorea leprosula, Shorea selanica, Hopea mengerawan dan Hopea dryobalanoides) di Hutan Penelitian Carita, memiliki model persamaan matematis yang berbeda.

4. Perlu dilakukan uji kesahihan (validity) terhadap model pertumbuhan diameter dan tinggi pohon yang telah dihasilkan tersebut.

\section{DAFTAR PUSTAKA}

Alder, D. 1980. Forest Volume Estimation and Yield Prediction. Vol 2 Yield Prediction. FAO. Rome.

Assmann, E. 1970. The Principles of Forest Yield Study. Pergamon Press. Oxford-New York-TorontoSydney-Braunschweig.

Chapman H.H. \& W.H. Meyer. 1949. Forest Mensuration. McGraw-Hill Book Company, Inc. New YorkToronto-London.

Harbagung. 1991. Model pertumbuhan diameter dan tinggi tegakan hutan tanaman Eucalyptus urophylla S.T. Blake. di daerah Pujon, Jawa Timur. Bul. P3H\&KA No. 545. 
Husch, B. 1963. Forest Mensuration and Statistics. The Ronald Press Company. New York.

Marcelino, M.M. 1966. A commercial volume table for Red Lauan (Shorea negrosensis Foxw) in Claveria, Cagayan Prov. The Phil. of For. No. 18. Dept. of Agr., and Resource, Manila.

Prodan, M. 1965. Holzmesslehre. JD. Sauerlaender's Verlag. Frankfurt am Main.

Spurr, S.H. 1952. Forest Inventory. The Ronald Press Company. New York.

Suhendang, E. 1996. Model pertumbuhan dan hasil hutan untuk pengusahaan hutan seumur. Fakultas Kehutanan IPB, Bogor. Tidak diterbitkan.

Vanclay, J.K. 1994. Modelling Forest Growth and Yield. Applications to Mixed Tropical Forests. CAB International, Wallingford. 